$4 C, 1$

W57k38

1911

NINAH

ONE DAY

WITH

WHISTLER

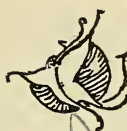

BY

FREDERICK KEPPEL

REPRINTED, BY PERMISSION, FROM

"THE READER" OF JANUARY, I9O4

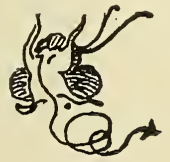

FREDERICK KEPPEL \& CO.

NEW YORK

19 I I 





Portrait of Whistler

From the drawing by Paul Rajon 



$$
\text { 过 }
$$




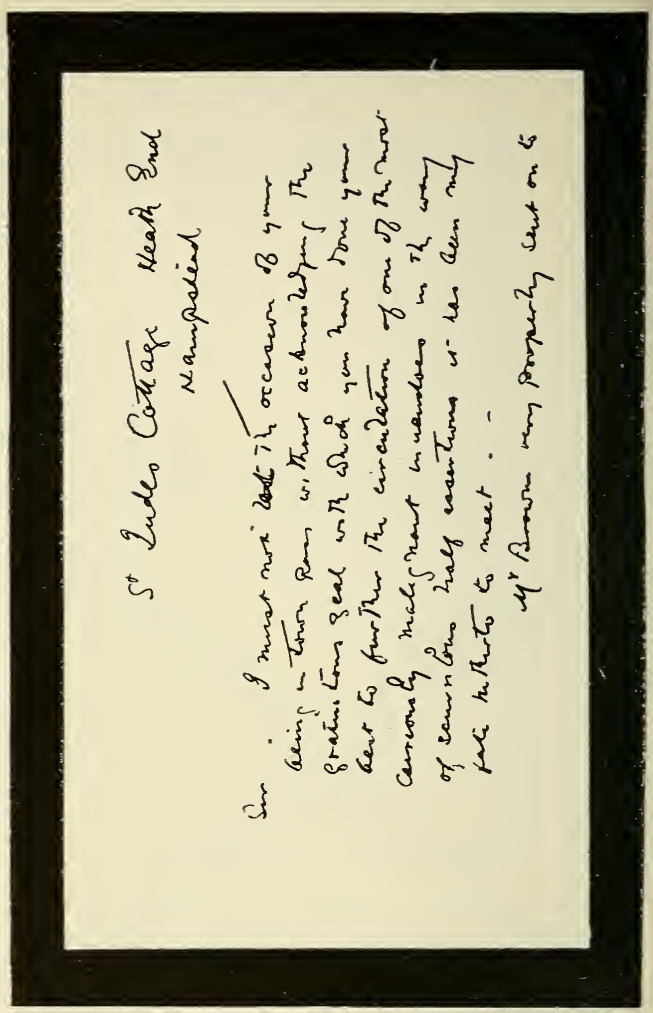




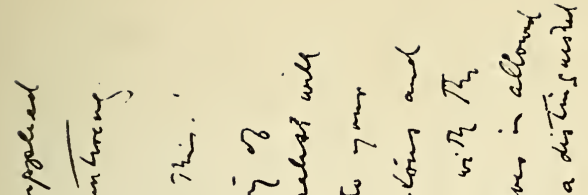

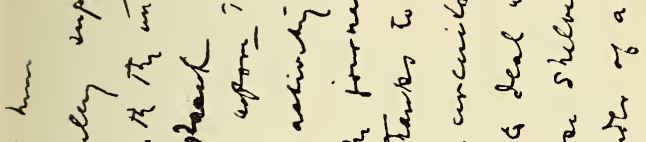

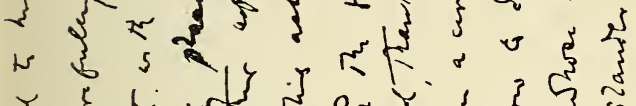
及

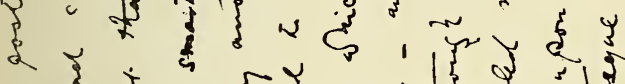

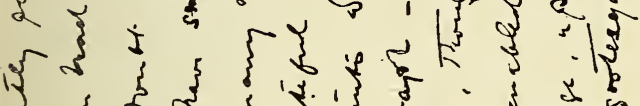



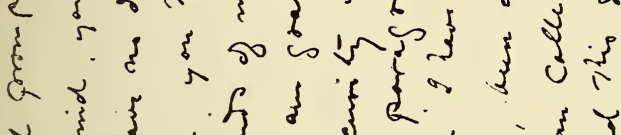

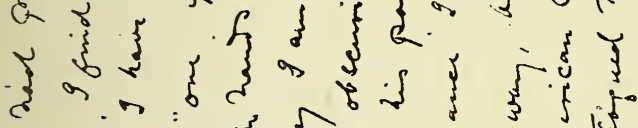

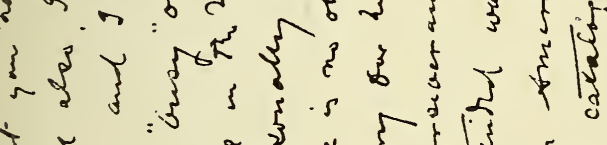

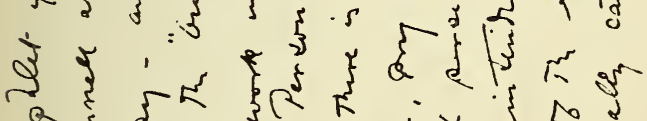

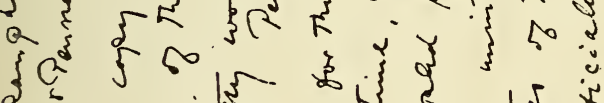

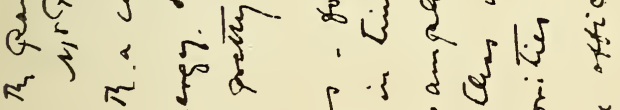

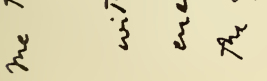

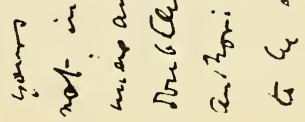




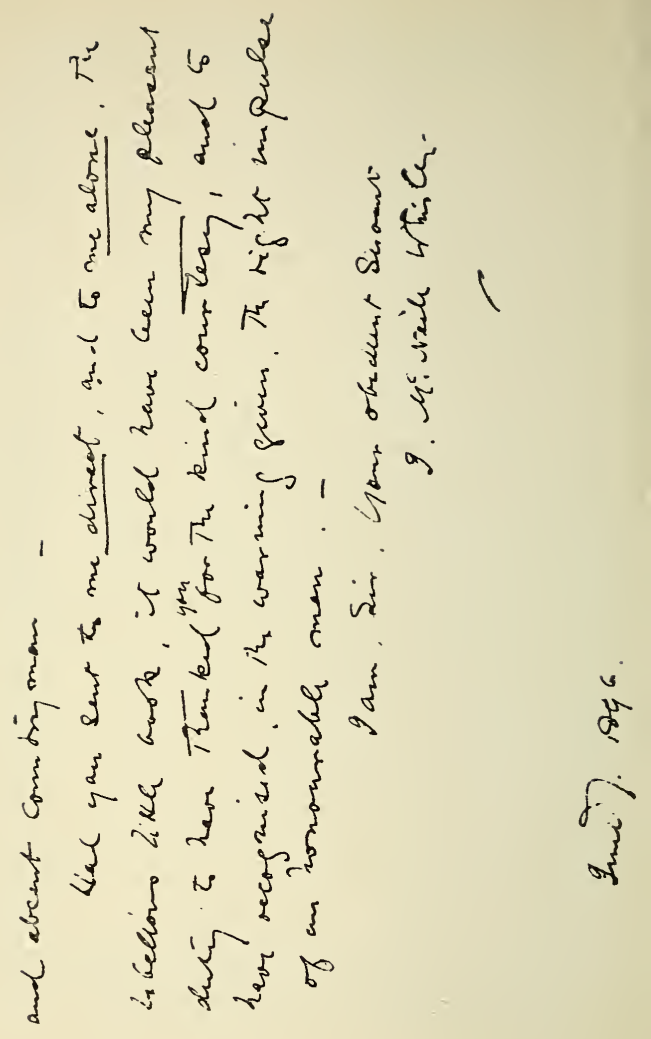




\section{ONE DAY WITH WHISTLER}

W of July, 1903, yet the more or less elaborate articles which have already been printed about him may be numbered by hundreds. Nor is the fascinating subject of this extraordinary personality by any means exhausted. More than one formal biography has appeared, and the monumental work of Mr. and Mrs. Pennell was published in the year 1908. The dual personality of Whistler - as a supreme master in art and as a supreme master of brilliant satirical wit-will continue to employ "the pen of the ready writer" for a long time to come.

If the old-time author's apologia for the appearance of some new book or treatise were still the fashion, I could make mine by simply stating that the present article contains nothing on the subject which has been printed 
before; seeing that it is the "unvarnished tale" (also the hitherto unpublished tale) of Whistler's intercourse with me and mine with him.

Our first meeting, long years ago, took place at his rooms in Tite Street, Chelsea. My errand did not concern myself at all: I simply undertook to deliver to him a picture entrusted to me at Whistler's request by an absent friend of his who toid me in French parlance the master would be visible from nine to ten o'clock every morning. I reached his house at about half past nine and was admitted by a servant who showed me into a reception room in which the prevailing color scheme was a pale and delicate yellow. The room at first looked bare and empty, yet its general effect was both novel and pleasing. Having sent up my card, upon which I had written a memorandum stating the cause of my visit, I soon heard a light step, and a moment later I set eyes on Whistler for the first time. It was his humor not to enter his own reception room, but to remain at the threshold glaring at me through his monocle and holding his watch open in his hand. There he was-the Whistler of so many portraits and so many caricatures-a slender, alert little man, but so gracefully proportioned 
that, as he stood framed in his own doorway, it was not easy to determine whether he was big, middle-sized, or small. All the external attributes or trade-marks were in evidence: the white lock above the middle of his forehead, carefully segregated from the black curls around it; the monocle stuck in his right eye and protected from breakage by a thin black cord which ran through a hole drilled near the edge of the crystal; the aggressive cravat and the very long black coat. Suddenly, with a disconcerting little detonation caused by the abrupt parting of his closed lips and with a simultaneous grimace, he caused the eye-glass to bounce outward from his eye, and having, like the patriarch Job, "opened his mouth," he said: "Now, I have just four minutes to spare: what is it that you want?" Let me here confess that I felt somewhat nettled at this unexpected reception - seeing that I had come long miles out of my way solely to oblige an absent friend of his and, incidentally, to oblige Whistler himself-and so I set myself to break down the repellent pose which he saw fit to assume. Having delivered to him the little picture which I had brought I gave him no immediate opening to snub me further. With this intent I talked about the friend who had sent 
me to him; I described to him the fine position in which his own contribution to the Paris Salon had been hung; I told him some flattering things which had been said by the right sort of people about it; I gave him news, which I knew would interest him, of other friends of his, and, like Browning's hero, I kept up "any noise bad or good," until he so far unbent as to enter the room where I was. Abruptly he then put the question to me: "Are you fond of pictures?" To this I made answer: "Such pictures as may be seen here, yes." "Come to the studio," said he; and thus began a memorable day which only ended when he had to go out to dine at eight in the evening, and even then he delayed-calmly remarking that people always waited dinner for him, no matter how late he came. This long day was passed in the studio except when we adjourned to the dining-room for lunch, where I remember that the table was decorated with vellow flowers and that the dishes were hollow, the hollow space being filled with boiling water for the purpose of keeping the eatables hot.

But it was in his studio that Whistler was at his brightest and best. Surely never was a man so far removed from being commonplace. His alert wit kept flashing like sum- 
mer lightning, and the pronouncement which Dr. Samuel Johnson delivered on his friend David Garrick might with equal force be applied to Whistler: "Sir, for sprightly conversation he is the foremost man in the world." Much of his talk that day was of a denunciatory character. Some eminent personages were severely castigated, but the vials of his bitterest wrath were poured on the devoted heads of certain prominent artists and more especially on those who painted portraits. While speaking on this subject he gave expression to one opinion which seems to be so sound and right that it should be recorded here: "To paint what is called a great portrait in England," said he, "the artist must overload everything with strong contrasts of violent colors. His success with the rich ignorant public is assured if only he succeeds in setting his colors shouting against each other. Go to the exhibition at the Royal Academy and see what is called the picture of the year-Mr. A's portralt of Mr. B. You can easily find it by seeing the crowd that stands staring at it all day long. Mix with this crowd and get near to the picture; fill your eye with it; then turn round and look at the faces of the living spectators, - - how quiet in tone they are! If A's portrait is right, 
surely every living man and woman you see in the crowd must be wrong!"

From all this depressing pessimism he rapidly turned to another subject which he proceeded to treat with enthusiastic optimism; for he began to talk of his own works. His delight in these was as frank and complete as the delight of some little boy who has triumphantly constructed a satisfactory mud pie.

There was standing on a perpendicular easel in the studio his superb portrait of the violinist, Sarasate-the same picture which afterward created such a sensation at the Paris Salon. The delighted artist conducted me through a doorway which faced the picture and, further on, to the end of a long corridor. There, turning round, we gazed on the picture framed in a vista of corridor and doorway. Laying his hand on my shoulder he said to me: "Now, is n't it beautiful?" "It certainly is," I answered. "No," said he, "but is n't it beautiful ?" "It is indeed," I replied. Then raising his voice to a scream, with a not too wicked blasphemy, and bringing his hand down upon his knee with a bang so as to give superlative emphasis to the last word of his sentence, he cried, ". it! Is n't it beautiful?" If I could do no other thing so well as Whistler, I could at 
least shout as loud as he could scream, so turning to him and adopting his little "swear word" (as a quotation, of course) I shouted into his face "__ - it, it is!" This third declaration seemed to satisfy him, and so we returned to the studio.

More manifestations of his delight in his own work were to follow: He had just received the proof sheets of his now famous book, "The Gentle Art of Making Enemies," and he asked me to read some of it aloud so that he could "hear how it sounded." Now I believe it is not possible for anyone to read a piece of fine literature aloud, and to do it well, unless he has read it before and knows what is coming in the text; and so I was not at all surprised when, after I had read a few pages to him, he called out "Stop! You are murdering it! Let me read it to you." $\mathrm{He}$ was quite right; I was murdering it! So we changed places. He read his own book admirably, and kept at it for about two hours. My enjoyment was, however, interrupted by a characteristic incident: His man-servant entered the studio: "Well?" said Whistler. "Lady Somebody, sir," said the servant (she was one of the great ladies of the British peerage). "Where is she?" "In her carriage at the door, sir." Whistler took no 
further notice of his servitor but resumed the reading of his proof sheets to me, and the puzzled footman, who was standing behind his master's back and facing me, shook his head slowly up and down, and-like Longfellow's Arabs-"silently stole away." Thus the reading went on for quite ten minutes longer, and the reader's sole auditor fidgeted more and more, till, realizing how deadly cold it was on that March day, I called out to him, "I beg your pardon, Mr. Whistler, but I think I overheard your servant telling you that a lady was waiting to see you." "Oh," said he, "let her wait, let her wait,I 'm mobbed with these people!" Then he went on reading for fully fifteen minutes more, and after that (his voice was getting tired, I dare say) he condescended to go down-stairs and receive her shivering ladyship.

Another incident of that day was the visit of a foreign artist, an old acquaintance, with whom Whistler had not-as yet-quarreled. $\mathrm{He}$ was received with genuine cordiality, and, artist-like, he ran round the studio looking at everything. One small picture seemed to charm him especially, and he said, "Now that is one of your good ones." "Don't look at it, dear boy," said Whistler, airily, "it 's not fin- 
ished." "Finished!" said the visitor. "Why, it is the most carefully finished picture of yours that I have ever seen." "Don't look at it!" persisted Whistler. "You are doing injustice to yourself, you are doing injustice to $\mathrm{my}$ picture-and you are doing injustice to me!" The visitor looked bewildered, when Whistler in a theatrical tone cried out, "Stop, I 'll finish it now!" Then he procured a very small camel's-hair brush, fixed it on a long and slender handle, mixed a little speck of paint on his palette, dipped the tip of his brush into it, and then, standing off from his picture, and with the action of a fencer with his rapier he lunged forward and touched the picture in one spot with his pigment. "Now it 's finished," said he. "Now you may look at it!" This was all highly dramatic, and indeed very well acted, but as in the case of some stage plays, the final act of Whistler's performance proved to be an anti-climax: the foreign artist took his leave, but finding that he had left his umbrella behind him, called for it next day. The servant, recognizing him, told him that Mr. Whistler had gone out for the day, but invited him to go to the studio and seek his umbrella. He went there and found it, but also took the opportunity of having one more look at the picture 
which had been "finished" for his special benefit the day before; and then he saw that the little dab of wet paint which Whistler had so dramatically put on he had afterward scrupulously wiped off again!

The kindly old Latin maxim which exhorts us to "Speak nothing but good concerning the dead" is appropriate for the millions of ordinary nobodies who disappear and are forgotten; but historical verity is most essential in the case of eminent or notable personalities whom the world will not forget. Thomas Carlyle was one such man and Lord Byron was another; but Mr. Froude so "edited" Carlyle's diary that no one is satisfied, and Thomas Moore suppressed Byron's diary altogether. Thus these two eminent men are not known to posterity as they each had deliberately planned to be known, and a serious danger of the same kind threatens the memory of Whistler. He was no coward-whatever other faults and eccentricities he may have manifested-and his life was consistent (in an inconsistent way) from first to last.

Yet some of the biographical notices which have already appeared try to make of him a sort of milk-and-water saint. This falsification may possibly do honor to the hearts of these writers-but certainly not to their 
heads!- and Whistler would never have approved of it. He took infinite pains, indeed, to let the world see his character as it actually was, and those who knew him best would agree with me in the opinion that all posthumous records of him should be written in the spirit of Othello's manly request when, knowing that he was about to die, he said:

Speak of me as I am; nothing extenuate, Nor set down aught in malice.

It is in this spirit that I now venture to give, as dispassionately as I can, the results of my long years of study of this extraordinary "human document," Whistler; and if I do not render my verdict worthless by covering him over with an indiscriminate coat of "whitewash," I have the precedent of his own book, "The Gentle Art of Making Enemies," to warrant me in telling the truth without fear or favor. Indeed, I shall not go so far as Whistler went, for in that book of his (with its felicitous title) he did not scruple to print numbers of letters from persons still living, and certainly without the consent of the several writers. It is quite another and an allowable thing to print private letters after the writers of them are dead; and many de- 
lightful books are made almost entirely from this source.

Whistler has often been called the greatest painter of his day-and he was always called the greatest etcher. If this proud position was accorded to him too tardily it was mainly through his own fault. It was his humor to antagonize the world in general; naturally the consequences reacted upon himself. The same cause would have brought about the same results in the case of Corot or Millet or Sargent or any other man of genius, for it was Whistler himself who deliberately made the hard bed in which he had to lie for many a year. "To the froward thou wilt show thyself froward" remains as true to-day as when it was written long ages ago.

One writer makes the statement that "there never has been and probably never shall be another man 'like Whistler." As to the future-we cannot tell; as to his own times, a satirical London reviewer wittily calls a whole group of artists "mainly pennyWhistlers," because they aped both the master's personality and his art, and in consequence were of no more value than a child's penny-whistle. But it is remarkable that no writer has as yet pointed out the strong resemblance between the man Whistler and the 
man Benvenuto Cellini. Whistler flourished some three and a half centuries later than the famous Florentine sculptor and goldsmith, who was born in the year 1500 ; each of the two has left an extraordinary book in which the author is the extravagantly vaunted hero; each of them spent much of his life in waging conflicts of his own making, and each records his own exploits with the most complacent self-satisfaction.

Mr. John Addington Symonds-the translator, apologist, and vindicator of Cellinifeels constrained to write of the Florentine: "Great though his talents were he vastly overrated them, and set a monstrously exaggerated value on his works of art. The same qualities made him a fierce and bitter rival; he could not believe that anyone with whom he came into collision had the right to stand beside him." Does not this extract make us almost feel that we are reading a paragraph from some current biography of Whistler?

But notwithstanding these self-created drawbacks his genius as an artist, coupled with his brilliant powers of pleasing (when he chose to please), resulted in the fact that Whistler's society was eagerly courted by the most eminent artistic and intellectual men and 
women of his day and generation. His faculty for inspiring people with enthusiasm for himself and for his pictures was simply marvellous. This effect which he wrought on his devotees was wittily described by the Paris writer, M. Henri Beraldi, as "the malady of Whistlerium Tremens" and (while it lasted) it was naturally delightful; but the day was sure to come when Whistler would suddenly "turn and rend" his former friend, and after that the friend was never forgiven. So often did this happen that it would be easy to make a tabular list of say a hundred names of more or less distinguished and amiable people who once stood high in the Whistlerian esteem, but of whom nearly everyone had the misfortune unconsciously to wound the master's enormous vanity, and so to be written down in his black books with indelible ink. Yet even in these sad circumstances Whistler never allowed his own interest to modify his wrath against the unconscious offender; indeed, if it was his special interest-monetary or otherwise-to maintain good relations with any man, that was the man of all others whom he was surest to "clapperclaw!"

Shakespeare tells us that "troops of friends" are one of the blessings which should accompany a happy old age, and Whistler's last 
years would have been desolate indeed were it not that a few - a very few-faithful souls clung to him to the end. I have particularly in mind an American couple residing in London, Mr. and Mrs. Joseph Pennell, who acted as his very efficient guardian angels to the last; "and all for love, and nothing for reward"-as old Edmund Spenser has it. .Theirs was the untiring fidelity which "beareth all things, believeth all things, hopeth all things, endureth all things!"

If I were asked why it was that Whistler so assiduously practised "the gentle art of making enemies" (instead of the still gentler art of making friends) I should answer: primarily because he liked it! He has on occasion recounted to me with high glee the details of one or another of his quarrels, and it must be admitted that he was a brilliant fighter; but such little matters as the logic or the equity of the question in dispute never troubled him at all. His faculty for "making the worse appear the better reason" was quite extraordinary, and often he first put himself entirely in the wrong and then fought a valiant-if a losing battle.

Another of his peculiarities was the histrionic cast of his nature. Queen Victoria once complained of her prime minister, Glad- 
stone. "He harangues me as if I were a public meeting." Similarly, Whistler was forever performing as if he were playing a comedy before an audience, and it was never easy to determine when he was in serious earnest and when he was only "poking fun." This same theatrical cast of his mind led him, years ago, to change his own name-for Whistler had no more right to assume the middle name of McNeill than the present writer would have to appropriate the middlename of Plantagenet or Hohenzollern. He was baptized James Abbott Whistler. This fact concerning his legal name is not known to many, but there is incontestable evidence of it; and in his later years there was no surer way of infuriating him than by giving him the name which he received in baptism. The poet Swinburne committed this unpardonable $\sin$ in the dedication of one of his poems. Another of these inconvenient little matters about which Whistler loved to mystify and befog the public is the fact that he was born on the Ioth of July, I834, in Worthen Street, Lowell, Mass. Such a stubborn fact as this, however, did not deter him from swearing, during the Sir William Eden lawsuit in Paris, that he was born in Russia! But in Whistler's case, as in the case of very 
imaginative little children (girls oftener than boys), we should be very careful of condemning them for deliberate lying when they only dramatize a series of imaginary things until at last they come to believe them.

People have often suggested to me that, in view of his eccentricities, Whistler must have been a little wrong in the head. Not he! I have never known a man whose intellect was clearer or more alert. His memory also was very accurate-more especially with regard to all the ins and outs of his numerous quarrels.

Still another of his characteristics was his way of imparting a look of careless precipitation to his later paintings and prints,- the truth being that, to the very last, he took infinite care with every detail of his work, and everyone who has sat to him for a portrait can testify that the master almost killed his sitter with fatigue by reason of his scrupulous exactions and repetitions. So long as he was at work on a picture he was intensely in earnest, and it was only in his intercourse with his fellow-men that he assumed the rôle of poser and performer. He would very rarely answer a letter, but, like Napoleon, generally assumed that a letter would answer itself through the subsequent event. One of 
the last friendly epistles which I received from him was in acknowledgment of a cutting from the New York Tribune, which I had sent him and which contained the announcement of his own marriage. This paragraph, being printed at the top of one of the pages of the newspaper, I utilized the inch of blank margin above by writing on it the following verse:

One Whistler more, one Godwin less,

Two Artists wed this day;

Long may you each the other bless,

So prays your friend F. K.

But the inevitable hour was to come when Whistler-like some supposedly tamed wild animal-must suddenly and unprovokedly turn and bite. In my case it happened in this wise: Two well-known American Librarians had collaborated in preparing a pamphlet which was entitled "Guide to the Stucy of James Abbott McNeill Whistler." It was published by the University of the State of New York at Albany and bore on its titlepage the names of the joint authors. The sole motive of both the compilers and the Regents of the University was to do honor to Whistler, but it appears that in the little book the incense burned was not pungent 
enough to suit the nostrils of the illustrious subject. Three copies of the pamphlet were sent to me. One of them I kept and the remaining two I sent respectively to Mr. Joseph Pennell and Mr. Ernest Brown in London. If I had had a fourth I would have sent it to Whistler himself in the belief that it would have given him pleasure. Six months afterward I arrived in London and was told by Lady Seymour Haden (Whistler's half-sister) that "her brother Jimmie" had buried his wife that same day. I had known and esteemed the deceased lady, and so I at once wrote to Whistler telling him that his sister had just told me of his bereavement and assuring him of my deep sympathy. My letter made mention of this and of nothing else. Next day (the day after his wife's funeral) I received from him a registered letter, the envelope bordered in deepest black and sealed in black wax with his mystic emblem or device of a sort of Whistlerized butterfly. I had not expected so early a reply to my letter of condolence, but when I came to read what he had written to me I certainly stared at it in amazement. Here follows his letter, and I do not think that in his published book there is a more brilliant specimen of characteristic abusive Whistlerism than this: 


\section{St. Jude's Cottage, Heath End, Hampstead.}

SIR: I must not let the occasion of your being in town pass without acknowledging the gratuitous zeal with which you have done your best to further the circulation of one of the most curiously malignant inuendoes, in the way of scurrilous half-assertions, it has been $\mathrm{my}$ fate hitherto to meet.

Mr. Brown very properly sent on to me the pamphlet you had promptly posted to him.

Mr. Pennell also, I find, you had carefully supplied with a copy-and I have no doubt that, with the untiring energy of the "busy" one, you have smartly placed the pretty work in the hands of many another before this.

Personally I am grateful to this activity of yours-for there is no obscurity into which the journalist will not, in time, pry for his paragraph-and, thanks to your unexampled perseverance, I have, though in a circuitous and doubtless unintended way, been enabled now to deal with the authorities of the American College, upon whose shelves is allowed to be officially catalogued this grotesque slander of a distinguished and absent countryman.

$\mathrm{Had}$ you sent to me direct, and to me alone, the libellous little book, it would have 
been my pleasant duty to have thanked you for the kind courtesy-and to have recognized, in the warning given, the right impulse of an honorable man.

I am, Sir, Your obedient servant, J. McNeill Whistler.

Two days later I got an opening to return his undeserved blow; but all that followed is of small interest to the public, who care very much about everything concerning Whistler, but very little about the lesser people who sometimes successfully repelled his unjust attacks. .

It is obvious that when I received the letter just cited, all my friendly intercourse with this extraordinary man came to an end.

Frederick Keppel. 


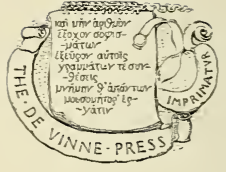


SMITHSONIAN INSTITUTION LIBRARIES

|||||||||||||||||||||||||||||

39088007907116 